Received 08.11.2017

Reviewed 12.12.2017

Accepted 16.01.2018

A - study design

B - data collection

C - statistical analysis

D - data interpretation

$\mathbf{E}$ - manuscript preparation

F - literature search

\section{Hydrological conditions of peatland formation based on a dynamic curve of a biogenic sediments sequence - a new proposal}

Krzysztof LIPKA ${ }^{\text {ABDEF }}$, Ewelina ZAJĄC ${ }^{\text {ABDEF } 凶}$

University of Agriculture in Krakow, Faculty of Environmental Engineering and Land Surveying,

Department of Land Reclamation and Environmental Development, al. Mickiewicza 24/28, 30-059 Kraków, Poland; e-mail: e.zajac@ur.krakow.pl

For citation: Lipka K., Zając E. 2018. Hydrological conditions of peatland formation based on a dynamic curve of a biogenic sediments sequence - a new proposal. Journal of Water and Land Development. No. 37 p. 75-85. DOI: 10.2478/jwld-2018-0027.

\begin{abstract}
The aim of the study was to propose a so called dynamic curve for identification of hydrological conditions of peatland formation. This method facilitates interpretation of accumulation processes based on sequence of biogenic sediments depending on variable hydrological conditions. Eleven types of hydrological conditions (HC) were distinguished and characterized with reference to ecohydrological interrelations governing the formation of peatlands. Each HC type was associated with specific peat type and species rendered in a classification for Central Europe. When employing a synthetic description of the identified HCs, it is possible to use the dynamic curve to provide a graphical representation of a hydration status for a geological profile and a general interpretation of the course of changes in water conditions during peatland development. The discussed method is somewhat simplified but it can be used for general interpretation of hydrological conditions of peatland development and would not require some highly specialized analyses. Such an approach may prove sufficient, particularly in engineering practice.
\end{abstract}

Key words: biogenic sediments sequence, dynamic curve, peatland geology, peatland hydrology, plant macrofossils

\section{INTRODUCTION}

Peatlands are specific ecosystems capable of accumulating residues of peat forming plants and thus formation of peat deposits. Functioning of these ecosystems depends primarily on such factors as hydrology, climate, chemistry, morphology and vegetation. These factors were used for developing numerous peatland classification systems and for explaining the patterns of their distribution [LINDSAY 2016; VITT 2006]. Most European classifications distinguish peatland types based on ecological and hydrological criteria. The ecological criterion defines the type of water supply, which determines trophic conditions of a habitat and thus species composition of peat forming plants (e.g. KULCZYŃSKI [1939-1940; 1949]; OŚWIT [1975]; DAMMAN, FRENCH [1987]; TOBOLSKI [2000]; WHEELER, Proctor [2000]). Peats are formed when plant residues are accumulated in the conditions of permanent paludification. One of their most important roles is archiving the history of natural environment. This is possible thanks to certain preservative properties that allow for a survival of easily destructible artefacts, such as plant macrofossils (e.g. CHAMBERS, CHARMAN [2004]; TOBOLSKI [2004]). Plant residues composition indicates the type of peat and reflects hydrological conditions of the peatforming process (e.g. OśwIT [1977]; OKRUSZKO 
[1983]; TUITILLA et al. [2007]). An analysis of plant residues may help in reconstructing subfossil communities and origin of a peatland. Peat types identified at various depths document plant communities prevailing at different times. Therefore, interpretation of a peat sequence may help in revealing the history of peatland formation.

Geology of peatlands is a rich source of data on both biotic and abiotic environments. First and foremost, it is widely used in paleoenvironmental studies to reconstruct hydrological changes and to understand hydrogeological determinants of peat-forming ecosystems (e.g. TOBOLSKI [2004]; ANDERSSON, SCHONING 2010]). The information retained in peat sediments allows for investigating climatic changes, dynamics of peat formation and carbon accumulation, and human impact on the peatland and its surroundings (e.g. BARBER [1993]; MAUQUOY et al. [2008]; LAMENTOWICZ et al. [2009]).

Modern high-resolution paleoenvironmental reconstructions use a multi-proxy approach based on quantitative abiotic and biotic proxies (e.g. VAN DER KNAAP et al. [2011]; GAŁKA et al. [2017]). Investigation of peatland paleohydrology involves not only plant macrofossils analysis but also pollen and nonpollen palynomorph analysis (e.g. testate amoebae), peat humification, and ash content that are supplemented by dating (e.g. ${ }^{14} \mathrm{C}$ method, dendrochronological method). Reconstruction of peatland paleo-water tables based on single-proxy analysis (e.g. plant macrofossils only) is less reliable than an interpretation involving multiple methods [VÄLIRANTA et al. 2012]. Although the multi-proxy approach provides a more comprehensive and reliable interpretation of peatland development conditions, some analyses require specialized background and scientific expertise.

The aim of the study was to present a proposal of using a so called dynamic curve for identification of hydrological conditions of peatland formation. This method may be used for general interpretation of the accumulation process based on the sequence of biogenic sediments depending on changes in source and state of water supply. It was developed with reference to a peat classification system commonly used in Poland. The study is intended at the presentation of the method alone, which is why detailed results of plant macrofossil analysis that serve as a basis for peat type identification are not presented here. At this stage, it should be treated as a preliminary proposal, as it requires validation against other methods of multiproxy type used for paleoenvironmental reconstruction to determine its error.

\section{MATERIAL AND METHODS}

Peatland formation was investigated based on dynamic curves in 16 sites located in different regions of Poland (Fig. 1). Table 1 lists their coordinates and location within physico-geographical units (macroand mesoregions) according to KONDRACKI [2011]

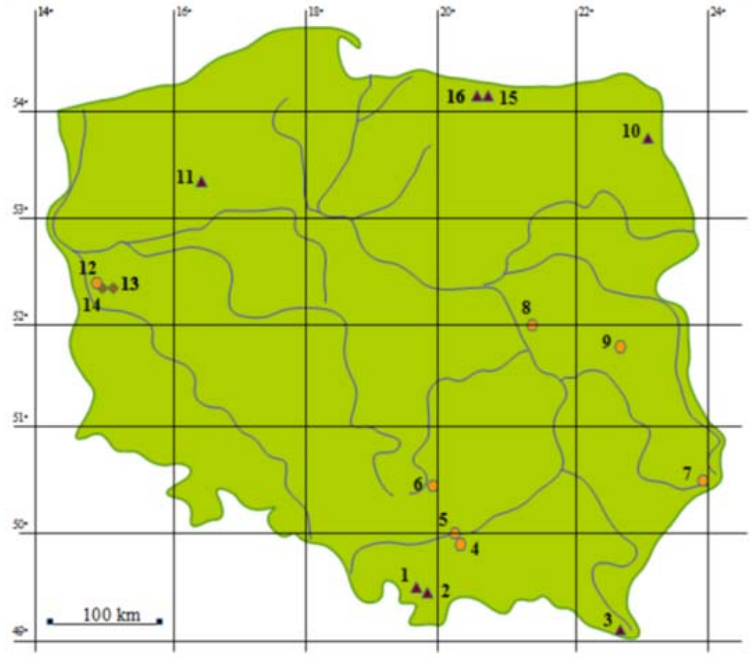

Fig. 1. Distribution of the investigated peatlands in Poland; type of peatland: $\bullet$ fen, $\triangle$ transitional bog, $\Delta$ raised bog,

$1-15=$ numbers of peatlands - explanations in Tab. 2; source: own elaboration

and in a relief. Mean annual temperature and precipitation for the multi-year period of 1951-2000 were provided for the nearest weather station after Woś [2010] - Table 1.

Geological surveying of the peatlands was conducted along transects laid out in a way that reflected representative features of the sites. We present selected typical geological profiles for which the dynamic curves were developed. Drillings down to the mineral substrate were performed with an Instorf corer (Eijkelkamp) equipped with a $50 \mathrm{~cm}$ cylinder of $5 \mathrm{~cm}$ diameter. The sampled sediments were examined in a laboratory. A degree of peat decomposition [PN-G04595; TOBOLSKI 2000] and composition of plant macrofossils were assessed with a microscopic method using available identification keys [KAC et al. 1977; MAUQuOY, VAN GeEL 2007; TOBOLSKI 2000]. To remove humus, the peat suspension was washed on a $0.2 \mathrm{~mm}$ mesh screen. Each sample was used to prepare three slides that were examined under a microscope at a magnification of 100-400 times. Ash content in the sediments was determined based on loss on ignition at $550^{\circ} \mathrm{C}$ in a sample previously dried to a constant weight, and carbonate content was assessed using Scheibler's method. The units of peat (types and species) were identified on the basis of plant macrofossils composition according to a genetic classification by TOŁPA et al. [1967; 1971], and the types of gyttja as per ILNICKI [2002].

Peatland zero boundary (min peat thickness $0.3 \mathrm{~m}$ ) was identified using a metal probe, and then it was used for calculations of peatland area. Average thickness of peat and gyttja was assessed as described in guidelines for peatland documentation [MR 1959]. Based on a source of water supply predominant type of hydrological feeding was determined for individual peatlands [DEMBEK, OŚWIT 1992; OKRUSZKO 1983]. 
Table 1. Basic physiographic and climatic characteristics of the investigated peatlands

\begin{tabular}{|c|c|c|c|c|c|c|c|}
\hline \multirow[t]{2}{*}{ No } & \multirow{2}{*}{ Peatland name } & \multicolumn{2}{|c|}{$\begin{array}{l}\text { Physicogeographic unit } \\
\text { acc. to KONDRACKI [2011] }\end{array}$} & \multirow[t]{2}{*}{ Geomorphological location } & \multicolumn{2}{|c|}{$\begin{array}{c}\text { Mean annual for the } \\
\text { period 1951-2000 }\end{array}$} & \multirow{2}{*}{\begin{tabular}{|c|} 
Geo- \\
graphical \\
coordinates
\end{tabular}} \\
\hline & & macroregion & mesoregion & & $P, \mathrm{~mm}$ & $T,{ }^{\circ} \mathrm{C}$ & \\
\hline 1 & Puścizna Wielka & $\begin{array}{l}\text { Orawa-Podhale } \\
\text { depression }\end{array}$ & $\begin{array}{l}\text { Orawa-Nowy Targ } \\
\text { Basin }\end{array}$ & $\begin{array}{l}\text { terrace within alluvial cone of } \\
\text { the ice-marginal valley of the } \\
\text { Czarny Dunajec River }\end{array}$ & \multirow{2}{*}{1111} & \multirow{2}{*}{6.1} & $\begin{array}{l}49^{\circ} 26^{\prime} 54^{\prime \prime} \mathrm{N} \\
19^{\circ} 46^{\prime} 10^{\prime \prime} \mathrm{E}\end{array}$ \\
\hline 2 & Bór za Lasem & $\begin{array}{l}\text { Orawa-Podhale } \\
\text { depression }\end{array}$ & $\begin{array}{l}\text { Orawa-Nowy Targ } \\
\text { Basin }\end{array}$ & $\begin{array}{l}\text { terrace within alluvial cone of } \\
\text { the ice-marginal valley of the } \\
\text { Czarny Dunajec Rriver }\end{array}$ & & & $\begin{array}{l}49^{\circ} 25^{\prime} 30^{\prime \prime} \mathrm{N} \\
19^{\circ} 48^{\prime} 18^{\prime \prime} \mathrm{E}\end{array}$ \\
\hline 3 & Wołosate & Eastern Beskidy & \begin{tabular}{|l|} 
Western \\
Bieszczady
\end{tabular} & $\begin{array}{l}\text { higher fluvial terrace of the } \\
\text { Wołosatka stream }\end{array}$ & 670 & 8.0 & $\begin{array}{l}49^{\circ} 04^{\prime} 46^{\prime \prime} \mathrm{N} \\
20^{\circ} 39^{\prime} 36^{\prime \prime} \mathrm{E} \\
\end{array}$ \\
\hline 4 & Targowisko & Sandomierz Basin & $\begin{array}{l}\text { Bochnia Foothills } \\
\text { (Wieliczka-Gdów } \\
\text { Plateau) }\end{array}$ & $\begin{array}{l}\text { old river-bed of the Raba } \\
\text { River }\end{array}$ & \multirow[b]{2}{*}{666} & \multirow[b]{2}{*}{7.9} & $\begin{array}{l}49^{\circ} 59^{\prime} 20^{\prime \prime} \mathrm{N} \\
20^{\circ} 18^{\prime} 04^{\prime \prime} \mathrm{E}\end{array}$ \\
\hline 5 & Wielkie Błoto & Sandomierz Basin & $\begin{array}{l}\text { Bochnia Foothills } \\
\text { (southern and mid- } \\
\text { dle part) } \\
\text { Nadwiślańska Low- } \\
\text { land (northern part) }\end{array}$ & $\begin{array}{l}\text { post-glacial depression on the } \\
\text { older fluvial terrace of the } \\
\text { Wisła River }\end{array}$ & & & $\begin{array}{l}50^{\circ} 17^{\prime \prime} \mathrm{N} \\
20^{\circ} 16^{\prime} 30^{\prime \prime} \mathrm{E}\end{array}$ \\
\hline 6 & Błonie & Nida Basin & Miechów Upland & valley of the Uniejówka River & 628 & 7.3 & $\begin{array}{l}50^{\circ} 27^{\prime} 21^{\prime \prime} \mathrm{N} \\
19^{\circ} 54^{\prime} 08^{\prime \prime} \mathrm{E} \\
\end{array}$ \\
\hline 7 & Wojsławka & Lublin Upland & Grabowiec Height & valley of the Wojsławka River & 574 & 7.4 & $\begin{array}{l}50^{\circ} 56^{\prime} 23^{\prime \prime} \mathrm{N} \\
23^{\circ} 266^{\prime} 26^{\prime \prime} \mathrm{E} \\
\end{array}$ \\
\hline 8 & Całowanie & $\begin{array}{l}\text { Middle Mazowsze } \\
\text { Lowland } \\
\end{array}$ & $\begin{array}{l}\text { Middle Wisła Val- } \\
\text { ley }\end{array}$ & $\begin{array}{l}\text { higher sandy dune terrace of } \\
\text { the middle Wisła River valley }\end{array}$ & 510 & 7.9 & $\begin{array}{l}51^{\circ} 59^{\prime} 33^{\prime \prime} \mathrm{N} \\
21^{\circ} 22^{\prime} 12^{\prime \prime} \mathrm{E} \\
\end{array}$ \\
\hline 9 & $\begin{array}{l}\text { Wieprz - Krzna (near } \\
\text { Radzyń Podlaski) }\end{array}$ & \begin{tabular}{|l|} 
South Podlasie \\
Lowland
\end{tabular} & Łuków Plain & valley of the Białka River & 532 & 7.5 & $\begin{array}{l}51^{\circ} 50^{\prime} 58^{\prime \prime} \mathrm{N} \\
22^{\circ} 52^{\prime} 20^{\prime \prime} \mathrm{E} \\
\end{array}$ \\
\hline 10 & $\begin{array}{l}\text { Koniuszki (upper } \\
\text { Biebrza basin) }\end{array}$ & $\begin{array}{l}\text { North Podlasie } \\
\text { Lowland } \\
\end{array}$ & Biebrza Basin & $\begin{array}{l}\text { valley of the upper Biebrza } \\
\text { River }\end{array}$ & 587 & 6.2 & \begin{tabular}{|l}
$53^{\circ} 41^{\prime} 45^{\prime \prime} \mathrm{N}$ \\
$23^{\circ} 29^{\prime} 38^{\prime \prime} \mathrm{E}$ \\
\end{tabular} \\
\hline 11 & Kłębowiec & $\begin{array}{l}\text { South Pomeranian } \\
\text { Lakeland }\end{array}$ & Wałcz Lakeland & valley of the Dobrzyca River & 544 & 8.4 & $\begin{array}{l}53^{\circ} 19^{\prime} 38^{\prime \prime} \mathrm{N} \\
16^{\circ} 26^{\prime} 51^{\prime \prime} \mathrm{E} \\
\end{array}$ \\
\hline 12 & Bielice & Lubusz Lakeland & Torzym Plain & $\begin{array}{l}\text { flow-through lake } \\
\text { in the Ilanka River valley }\end{array}$ & \multirow{3}{*}{588} & \multirow{3}{*}{8.4} & $\begin{array}{l}52^{\circ} 21^{\prime} 20^{\prime \prime} \mathrm{N} \\
14^{\circ} 59^{\prime} 07^{\prime \prime} \mathrm{E} \\
\end{array}$ \\
\hline 13 & Pniów I & Lubusz Lakeland & Torzym Plain & evorsion lake & & & $\begin{array}{l}52^{\circ} 20^{\prime} 56^{\prime \prime} \mathrm{N} \\
15^{\circ} 01^{\prime} 16^{\prime \prime} \mathrm{E} \\
\end{array}$ \\
\hline 14 & Pniów II & Lubusz Lakeland & Torzym Plain & evorsion lake & & & $\begin{array}{l}52^{\circ} 20^{\prime} 58^{\prime \prime} \mathrm{N} \\
15^{\circ} 00^{\prime} 49^{\prime \prime} \mathrm{E}\end{array}$ \\
\hline 15 & Piersele & $\begin{array}{l}\text { Staropruska Low- } \\
\text { land }\end{array}$ & Sępopol Plain & kettle hole & \multirow{2}{*}{623} & \multirow{2}{*}{7.1} & $\begin{array}{l}54^{\circ} 21^{\prime} 02^{\prime \prime} \mathrm{N} \\
20^{\circ} 40^{\prime} 10^{\prime \prime} \mathrm{E} \\
\end{array}$ \\
\hline 16 & Warszkajty & $\begin{array}{l}\text { Staropruska Low- } \\
\text { land }\end{array}$ & Sępopol Plain & kettle hole & & & $\begin{array}{l}54^{\circ} 21^{\prime} 07^{\prime \prime N} \\
20^{\circ} 38^{\prime} 27^{\prime \prime} \mathrm{E}\end{array}$ \\
\hline
\end{tabular}

Explanations: $P=$ precipitation, $T=$ air temperature. Source: own elaboration.

Table 2. Hydrological conditions for dynamic curves of biogenic sediment sequence in peat deposit

\begin{tabular}{|c|l|}
\hline Symbol & \multicolumn{1}{|c|}{ Hydrological conditions (HC) } \\
\hline 0 & no peat-forming process \\
\hline I & depressions in the terrain, lake basins filled with water; sedimentation processes of bottom deposits \\
\hline II & $\begin{array}{l}\text { nearly all year long flood, predominantly stagnant water with no distinct movements and supplemented with precipitation A.1.1 } \\
3,4,5^{* *}\end{array}$ \\
\hline III & $\begin{array}{l}\text { ombrogenic-inundation water regime with decreasing inundation; higher location in a terrace system, less often floods in valleys, } \\
\text { river accumulation phase A.1.2* } ; 6,7,8^{* *}\end{array}$ \\
\hline IV & periodic groundwater inundation, short-term river floods followed by decrease in the peatland hydration A.1.3, A.2.3 $; 12,13,14^{* *}$ \\
\hline V & $\begin{array}{l}\text { flow through (drainage) water regime, constant supply of groundwater sometimes combined with inundation water; A.2.1, A.2.2 } \\
9,10^{* *}\end{array}$ \\
\hline VI & $\begin{array}{l}\text { undecided hydrological regime; permanent but very weak water drainage or its complete cessation, ombrogenic-flow through water } \\
\text { regime with weak share of the latter B.1, B.2. } ; 15,16,17^{* *}\end{array}$ \\
\hline VII & ombrogenic water regime; progressive rise of water level in the peat with periodic (seasonal) fluctuations of its location; $20^{* *}$ \\
\hline VIII & $\begin{array}{l}\text { ombrogenic water regime; accumulation of rainwater in peat maintained by capillary action, leading to rise in water level in peat; } \\
\text { water level rises with progression of hollow-hummock cycle; hollows in hollow-hummock cycle or "treeless-hollow phase" } 18^{* *}\end{array}$ \\
\hline IX & $\begin{array}{l}\text { ombrogenic water regime; lowering of water level, hummocks in hollow-hummock cycle or "hummock-forest phase" } 19,21,22, \\
24^{* *}\end{array}$ \\
\hline X & secondary decomposition of organic mass caused by frequent and considerable lowering of water level, amorphous peat XI ${ }^{* *}$ \\
\hline D & inhibition of peat formation process due to peatland drainage; initiation of degradation (moorsh forming process) \\
\hline
\end{tabular}

${ }^{*}$ Symbols denoting hydrological conditions according to the classification of peatlands by KULCZYŃSKI and commented on by OKRUSZKO and Oświt [1991].

${ }^{* *}$ Peat species numbers according to the classification of ToŁPA et al. [1976].

Source: own elaboration based on LIPKA [2000] and LIPKA, ZAJĄC [2014]. 
Table 3. Quantitative and qualitative data on the investigated peatlands

\begin{tabular}{|c|c|c|c|c|c|c|c|c|c|c|c|}
\hline \multirow[t]{2}{*}{ No } & \multirow[t]{2}{*}{ Peatland name } & \multirow{2}{*}{$\begin{array}{c}\text { Area } \\
\text { ha }\end{array}$} & \multirow{2}{*}{$\begin{array}{l}\text { Type of hy- } \\
\text { drological } \\
\text { feeding }\end{array}$} & \multirow{2}{*}{$\begin{array}{c}\text { Peatland } \\
\text { type }\end{array}$} & \multirow{2}{*}{$\begin{array}{l}\text { Peat } \\
\text { deposit } \\
\text { type }\end{array}$} & \multicolumn{2}{|c|}{$\begin{array}{l}\text { Thickness of } \\
\text { peat/gyttja, m }\end{array}$} & \multirow{2}{*}{$\begin{array}{c}\text { Dominant } \\
\text { peat species }\end{array}$} & \multirow{2}{*}{$\begin{array}{l}\mathrm{D}, \% \\
\text { mean } \\
\text { (range) }\end{array}$} & \multirow{2}{*}{$\begin{array}{l}\mathrm{A}, \% \\
\text { mean } \\
\text { (range) }\end{array}$} & \multirow[t]{2}{*}{ References } \\
\hline & & & & & & mean & $\max$ & & & & \\
\hline 1 & $\begin{array}{l}\text { Puścizna } \\
\text { Wielka }\end{array}$ & 482 & ombrogenous & $\mathrm{R}$ & $\mathrm{R}$ & $2.79 /-$ & $6.25 /-$ & \begin{tabular}{|l|} 
Eriophoro- \\
-Sphagneti
\end{tabular} & $\begin{array}{c}16.5 \\
(5.0-55.0)\end{array}$ & $\begin{array}{c}2.6 \\
(1.0-7.0)\end{array}$ & $\begin{array}{l}\text { LIPKA, ZAJAcC } \\
{[2014]}\end{array}$ \\
\hline 2 & Bór za Lasem & 55 & ombrogenous & $\mathrm{R}$ & $\mathrm{R}$ & $1.80 /-$ & $3.65 /-$ & \begin{tabular}{|l|} 
Eriophoro- \\
-Sphagneti
\end{tabular} & $\begin{array}{c}30.0 \\
(5.0-65.0)\end{array}$ & $\begin{array}{c}2.2 \\
(1.0-5.0)\end{array}$ & $\begin{array}{l}\text { LIPKA, ZAJĄC } \\
{[2014]}\end{array}$ \\
\hline 3 & Wołosate & 4 & $\begin{array}{l}\text { soligeneous- } \\
\text {-ombro- } \\
\text { geneous }\end{array}$ & $\mathrm{R}$ & $\mathrm{R}$ & $1.95 /-$ & $3.70 /-$ & \begin{tabular}{|l|} 
Eriophoro- \\
-Sphagneti
\end{tabular} & $\begin{array}{c}45.0 \\
(35.0-50.0)\end{array}$ & $\begin{array}{c}6.9 \\
(3.05- \\
18.30)\end{array}$ & $\begin{array}{l}\text { LIPKA, } \\
\text { GODZIEMBA- } \\
\text {-CZYŻ [1970], } \\
\text { LIPKA [1995] }\end{array}$ \\
\hline 4 & Targowisko & 25 & \begin{tabular}{|l|} 
soligeneous- \\
-fluvio- \\
geneous
\end{tabular} & $\mathrm{F}$ & $\mathrm{F}$ & $\begin{array}{l}3.53 / \\
1.09\end{array}$ & $\begin{array}{l}4.50 / \\
1.80\end{array}$ & $\begin{array}{c}\text { Cariceto- } \\
- \text { Phragmiteti }\end{array}$ & $\begin{array}{c}35.0 \\
(30.0-65.0)\end{array}$ & $\begin{array}{r}26.5 \\
(13.4- \\
41.3)\end{array}$ & un. sup. \\
\hline 5 & Wielkie Błoto & 265 & $\begin{array}{l}\text { soligeneous- } \\
\text {-fluvio- } \\
\text { geneous }\end{array}$ & $\mathrm{F}$ & $\mathrm{F}$ & $\begin{array}{l}1.72 / \\
0.75\end{array}$ & $\begin{array}{l}4.30 / \\
2.10\end{array}$ & $\begin{array}{c}\text { Cariceto- } \\
- \text {-Phragmiteti }\end{array}$ & $\begin{array}{c}35.0 \\
(25.0-65.0)\end{array}$ & $\begin{array}{c}23.1 \\
(11.5- \\
38.2)\end{array}$ & $\begin{array}{l}\text { LIPKA [1973; } \\
\text { 1989], LIPKA } \\
\text { et al. [2006] } \\
\text { sup. }\end{array}$ \\
\hline 6 & Błonie & 100 & \begin{tabular}{|l|} 
soligeneous- \\
-fluvio- \\
geneous
\end{tabular} & $\mathrm{F}$ & F & $2.34 /-$ & $5.00 /-$ & $\begin{array}{c}\text { Cariceto- } \\
\text {-Phragmiteti }\end{array}$ & $\begin{array}{c}45.0 \\
(15.0-85.0)\end{array}$ & $\begin{array}{c}26.0 \\
(15.2- \\
35.2)\end{array}$ & \begin{tabular}{|l} 
LIPKA et al. \\
[1977], LIPKA \\
[2000] sup.
\end{tabular} \\
\hline 7 & Wojsławka & 157 & \begin{tabular}{|l|} 
soligeneous- \\
-fluvio- \\
geneous
\end{tabular} & $\mathrm{F}$ & F & $2.44^{*}$ & $5.20^{*}$ & $\begin{array}{l}\text { Cariceto- } \\
\text {-Bryaleti }\end{array}$ & $\begin{array}{c}30.0 \\
(25.0-65.0)\end{array}$ & $\begin{array}{c}11.1 \\
(7.8-17.2)\end{array}$ & $\begin{array}{l}\text { LIPKA [2000] } \\
\text { sup. }\end{array}$ \\
\hline 8 & Całowanie & 1200 & $\begin{array}{l}\text { soligeneous- } \\
\text {-fluvio- } \\
\text { geneous }\end{array}$ & $\mathrm{F}$ & $\mathrm{F}$ & $\begin{array}{l}2.34 / \\
0.60\end{array}$ & $\begin{array}{l}3.50 / \\
1.00\end{array}$ & \begin{tabular}{|c|} 
Cariceto- \\
-Bryaleti, \\
Cariceto- \\
-Phragmiteti \\
\end{tabular} & $\begin{array}{c}45.0 \\
(25.0-65.0)\end{array}$ & $\begin{array}{l}20.1 \\
(6.7- \\
49.15)\end{array}$ & $\begin{array}{l}\text { OŚwIT, } \\
\text { DEMBEK } \\
\text { [2001] sup. }\end{array}$ \\
\hline 9 & $\begin{array}{l}\text { Wieprz-Krzna } \\
\text { (near Radzyń } \\
\text { Podlaski) }\end{array}$ & 1710 & fluviogeneous & $\mathrm{F}$ & F & $\begin{array}{l}1.5 / \\
0.76\end{array}$ & $\begin{array}{c}3.75 / \\
1.7\end{array}$ & $\begin{array}{c}\text { Cariceto- } \\
- \text { Phragmiteti }\end{array}$ & $\begin{array}{c}40.0 \\
(30.0-65.0)\end{array}$ & $\begin{array}{c}10.2 \\
(7.1-16.5)\end{array}$ & $\begin{array}{l}\text { LIPKA [1984; } \\
\text { 2000] sup. }\end{array}$ \\
\hline 10 & \begin{tabular}{|l} 
Koniuszki \\
(Basen Górnej \\
Biebrzy)
\end{tabular} & 70 & \begin{tabular}{|l} 
soligeneous- \\
-fluvio- \\
geneous
\end{tabular} & $\mathrm{F}$ & F & $\begin{array}{l}3.49 / \\
0.90\end{array}$ & $\begin{array}{l}6.75 / \\
1.50\end{array}$ & $\begin{array}{l}\text { Cariceti, } \\
\text { Cariceto- } \\
\text {-Bryaleti } \\
\end{array}$ & $\begin{array}{c}35.0 \\
(25.0-75.0)\end{array}$ & $\begin{array}{c}12.7 \\
(7.2-22.4)\end{array}$ & LIPKA [2000] \\
\hline 11 & Kłębowiec & 54 & \begin{tabular}{|l} 
loligeneous- \\
-fluvio- \\
geneous
\end{tabular} & $\mathrm{F}$ & $\mathrm{F}$ & $\begin{array}{l}1.03 / \\
0.98\end{array}$ & $\begin{array}{l}1.75 / \\
1.25\end{array}$ & Alneti & $\begin{array}{c}40 \\
(35.0-60.0)\end{array}$ & $\begin{array}{c}16.6 \\
(1.9-26.4)\end{array}$ & un. sup. \\
\hline 12 & Bielice & 65 & $\begin{array}{l}\text { soligeneous- } \\
\text {-fluvio- } \\
\text { geneous }\end{array}$ & $\mathrm{F}$ & $\mathrm{F}$ & $\begin{array}{l}2.86 / \\
1.95\end{array}$ & $\begin{array}{l}5.75 / \\
5.25\end{array}$ & Alneti & $\begin{array}{c}49.0 \\
(35-60)\end{array}$ & $\begin{array}{c}22.6 \\
(8.5-31.4)\end{array}$ & \begin{tabular}{|l|} 
LIPKA, \\
FRANKIEWICZ \\
[1981] sup. \\
\end{tabular} \\
\hline 13 & Pniów I & 1.5 & ombrogenous & $\mathrm{T}$ & $\mathrm{R}$ & $1.93 /-$ & $2.10 /-$ & Eusphagneti & $\begin{array}{c}15.0 \\
(10.0-25.0) \\
\end{array}$ & $\begin{array}{c}10.4 \\
(4.8-21.2) \\
\end{array}$ & un. sup. \\
\hline 14 & Pniów II & 0.5 & ombrogenous & $\mathrm{T}$ & $\mathrm{R}$ & $\begin{array}{l}7.77 / \\
0.65\end{array}$ & $\begin{array}{l}8.25 / \\
0.75 \\
\end{array}$ & \begin{tabular}{|l|} 
Eriophoro- \\
-Sphagneti \\
\end{tabular} & $\begin{array}{c}25.0 \\
(10.0-55.0) \\
\end{array}$ & \begin{tabular}{|c|}
7.1 \\
$(4.4-14.9)$ \\
\end{tabular} & un. sup. \\
\hline 15 & Piersele & 28 & \begin{tabular}{|l|} 
topogenous- \\
-ombrogenous
\end{tabular} & $\mathrm{R}$ & $\mathrm{R}$ & $\begin{array}{l}2.46 / \\
1.05 \\
\end{array}$ & $\begin{array}{l}5.10 / \\
2.10 \\
\end{array}$ & \begin{tabular}{|l|} 
Eriophoro- \\
-Sphagneti
\end{tabular} & $\begin{array}{c}33.0 \\
(30.0-60.0) \\
\end{array}$ & $\begin{array}{c}6.2 \\
(2.2-14.1) \\
\end{array}$ & un. sup. \\
\hline 16 & Warszkajty & 8 & ombrogenous & $\mathrm{R}$ & $\mathrm{R}$ & $\begin{array}{c}4.95 / \\
0.54\end{array}$ & $\begin{array}{l}10.0 / \\
0.75\end{array}$ & Eusphagneti & $\begin{array}{c}7.0 \\
(5.0-10.0)\end{array}$ & \begin{tabular}{|c|}
4.8 \\
$(2.6-9.2)$
\end{tabular} & un. sup. \\
\hline
\end{tabular}

Explanations: type of peatland/peat deposit: $\mathrm{F}=$ fen, $\mathrm{T}=$ transition, $\mathrm{R}=$ raised, $\mathrm{D}=$ degree of peat decomposition, $\mathrm{A}=$ ash content, un. = unpublished data; sup. $=$ supplemented data; $*=$ whole deposit.

Source: own elaboration.

Characteristic qualitative and quantitative data on peatlands are presented in Table 3. Some studies were conducted in the years 1968-1980 when an inventory and documentation of peatlands in Poland were performed. These findings were supplemented in later years and partially published (references provided in Table 3).

\section{DYNAMIC CURVE OF THE BIOGENIC SEDIMENT SEQUENCE}

From a geological perspective, peat is a quaternary biogenic deposit classified as a sedimentary rock [MizerSKI, SYLWESTRZAK 2002], so it may be de- scribed using lithological criteria and subjected to petrographic characteristics [TOBOLSKI 2004]. The characteristics of the sedimentary rock stratigraphy involve determination of sedimentary environments in which the rocks were formed. Their origin and history may be described using a dynamic curve of a lithostratygraphic profile that is a petrographic approach [ALEXANDROWICZ 1978] reflecting the dynamics of sedimentary environments.

Here we propose to use a similar dynamic curve for peatlands, as from a petrographic perspective peat is a biogenic deposit formed in a sedimentary environment conditioned by water presence. Analysis of hydrological and phytosociological relationships re- 
sulted in distinguishing eleven types of hydrological conditions (HC) (Tab. 2) that may facilitate peat formation (in earlier papers e.g. LIPKA [2000], LIPKA, ZAJĄC [2014] "hydrological conditions" were called "aquatic environments"). They are associated with specific peat species set out in the classification for Central Europe published by TOŁPA et al. [1967; 1971]. This classification is based on a genetic association of peat with botanical composition of the plant communities of which it was formed.

Designated HC (Tab. 2) were marked with symbols $(0$, I, II ... D) and described with reference to the type of biogenic sediment (bottom deposits, peats) considering source and movements of supplying water and state of a peat-forming process (peat accumulation or degradation). Peat species that were formed by specific phytocoenoses may be treated as "indicators" of typical HC (water quality and its table within a peatland) prevailing in a given period. When employing a synthetic description of the identified HCs, it is possible to use the dynamic curve to provide a graphical representation of a hydration status for a geological profile and a general interpretation of the course of changes in water conditions during peatland development. In graphical presentation dynamic curve is a „stepped" line, which is a result of a time scale, frequency of sample collection. In fact, dynamics of water conditions followed by changes in peat-forming vegetation is reflected by smooth curvilinear course.

The proposed dynamic curve method is a simplified tool that yields data on the dynamics of changes in the ecohydrological system of a peatland but without explaining their causes.

\section{RESULTS AND DISCUSSION}

\section{GENERAL CHARACTERISTICS OF THE EXAMINED PEATLANDS}

The examined peatlands were of fen (9), bog (5) and transitional (2) type. Bogs were characterized by ombrogenic water supply, and soligenic-fluviogenic feeding prevailed in fens (Tab. 3). Gyttja of variable thickness underlaid peats in nine sites. The greatest mean $(1.95 \mathrm{~m})$ and maximum $(5.25 \mathrm{~m})$ thickness of this sediment was noted in Bielice (No 12) peatland. A dominant fen peat species was sedge-reed (Cariceto-Phragmiteti), while alder (Alneti) and reed (Phragmiteti) peats were less common. Bog peats were represented mainly cotton grass-Sphagnum (Eriophoro-Sphagneti) and hummock Sphagnum (Eusphagneti). These peats often formed several meters thick layers. In general, bog peats showed lower decomposition degree as well as ash content than fen peats. Transitional peats were rare and formed only shallow layers in the roof and bottom of the deposits. Considering total thickness of peat and gyttja, the thickest deposits were identified in Warszkajty $(10.75 \mathrm{~m})$, Bielice (10.0 m) and Pniów II (9.0 m) - Table 3.

\section{PEATLAND DEVELOPMENT BASED ON A DYNAMIC CURVE}

Abundant data on wetlands, defined as areas covered with materials accumulated at the surface as a result of water presence or with vegetation adapted for life in saturated soil conditions (so peatland and non-peatland areas), allowed for identification of considerable typological differences among geomorphological zones and physico-geographic regions of Poland [DEMBEK et al. 2000; ILNICKI 1996; OKRUSZKO et al. 2001; ŻUREK 1987]. A relationship was also confirmed between a landscape position of wetland and major source of water (precipitation, groundwater or surface waters), as the supply and runoff conditions determine the level and fluctuations of water table and therefore shape the ecohydrological conditions [DEMBEK, OŚWIT 1992; ŁAJCZAK 2013; OKRUSZKO 1992]. To illustrate these differences, the dynamic curves were developed for selected sites from different regions of Poland, that were formed under diverse geomorphological conditions. They were divided into three categories: mountain peatlands (Fig. 2A-C), peatlands formed in old glacial area of southern, eastern and central Poland (Fig. 2D-J), and peatlands developed in young glacial area of northern Poland (Fig. 2K-P).

In mountainous regions, the peatlands were formed within watersheds and flattened or basinshaped areas of slopes, particularly those covered with poorly permeable mineral substrate. Climatic conditions prevailing in these regions favoured peatland development. An increase in precipitation and a decrease in air temperature along with height promote development of raised bogs. Young glacial area has highly diversified landforms (outwash plains, moraine uplands, tunnel valleys, ice marginal valleys, etc.) with plentiful depressions. In this relief, peatlands often develop within lakes or depressions of different size. Contrary to this, old glacial area is characterized by a low number of depressions and greater denudation. In general, peat covered areas in this relief occurred rather within ice-marginal valleys and plains than highlands. Peatland development took place in various locations of extensive river valleys and was determined by a supply of surface and groundwater (see ŻUREK [1987]; DEMBEK et al. [2000]).

Below are examples of using dynamic curves for investigating hydrological determinants of peatland development based on the sediment sequence. The symbols of hydrological conditions (HC) in Figure 2 and in the text discussing the figures are as defined in Table 2. However, it should be stressed that complete recognition of peatland origin requires an analysis of a number of geological profiles from representative zones of the investigated sites, as they provide data not only on sediment sequence in vertical layout but also on their zonal variability in horizontal arrangement. 


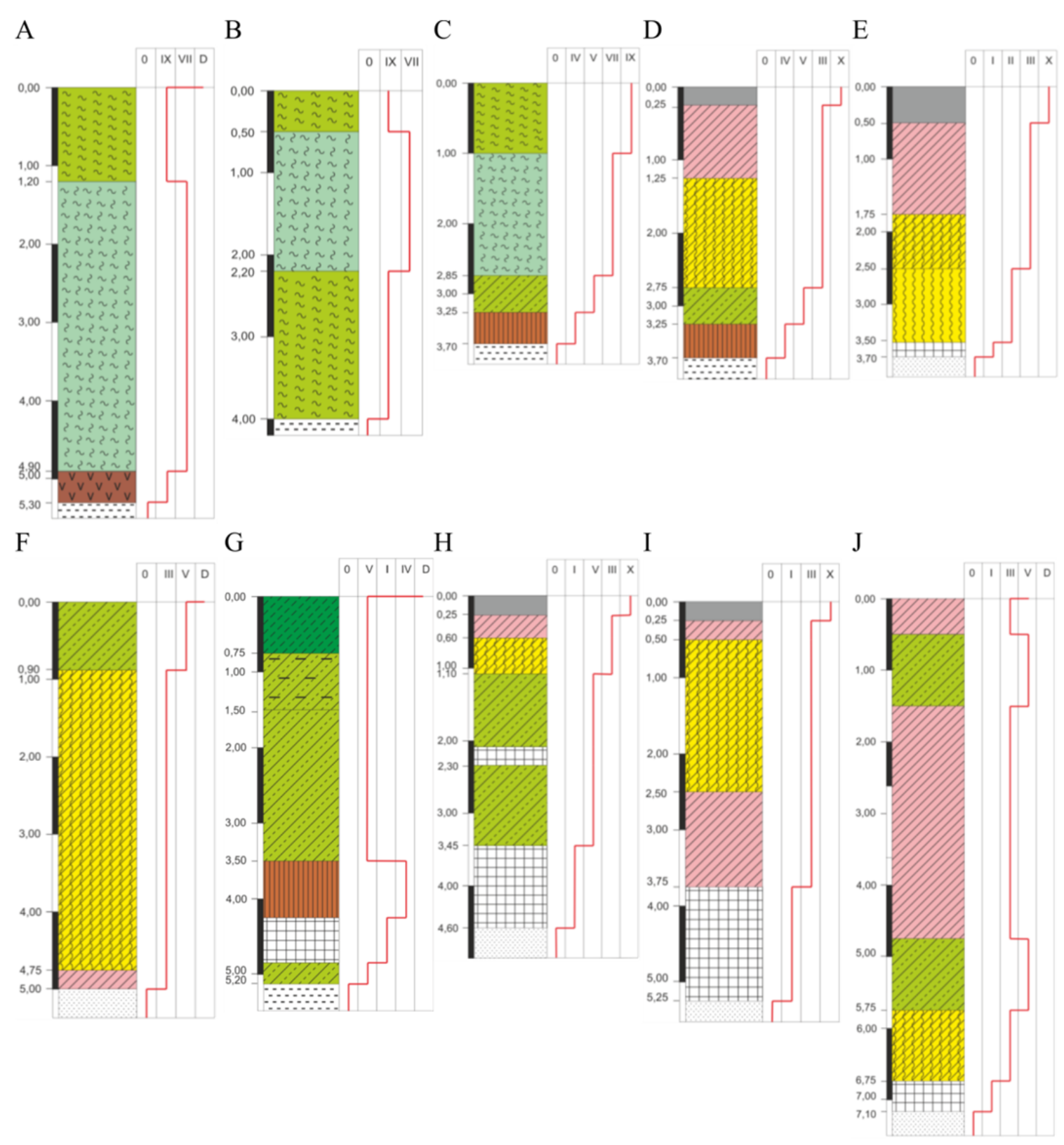

\section{MOUNTAIN PEATLANDS}

Puścizna Wielka (No 1) (Fig. 2A) and Bór za Lasem (No 2) (Fig. 2B) bogs located in Orava-Nowy Targ Basin were formed as a result of paludification of a poorly permeable clay substrate. Uplifting of the bog domes was associated with growing prevalence of ombrotrophic water supply that resulted in extreme oligotrophization of habitat. Peat was usually formed in HC VII, that is when progressive rise of water level in the peat was associated with its periodic fluctuations. These hydrological conditions were conducive to the formation of cotton grass-Sphagnum peat of considerable thickness. When lowered water level was maintained for longer periods, corresponding to HC IX, hummock Sphagnum peat was formed or, as in bottom layers of Puścizna Wielka bog, pine wood (Pineti) peat.
A Wołosate bog (No 3) (Fig. 2C), located in Western Bieszczady, has a different origin. Its formation began with accumulation of fen peats in the valley of the Wołosatka. At the bottom of the deposit alder peat was formed in $\mathrm{HC} \mathrm{IV}$, i.e. under short-time river inundation. The overlying sedge-moss (Cariceto-Bryaleti) peat indicated a gradual increase in feeding of the peatland with groundwater $(\mathrm{HC} \mathrm{V})$. Geological profile of this peatland revealed the presence of fen peats directly followed by bog peats of cotton grass-Sphagnum (HC VII) and hummock Sphagnum (HC IX) type. Their presence was due to the cessation of water drainage through the peatland and a shift towards ombrogenic alimentation. A thin layer of transitional peat, covering a layer of the fen peat, was found only in the central part of the peatland [LIPKA 1995]. According to KULCZYŃSKI [1939-1940; 1949], radical hydrological changes leading to oligotrophiza- 


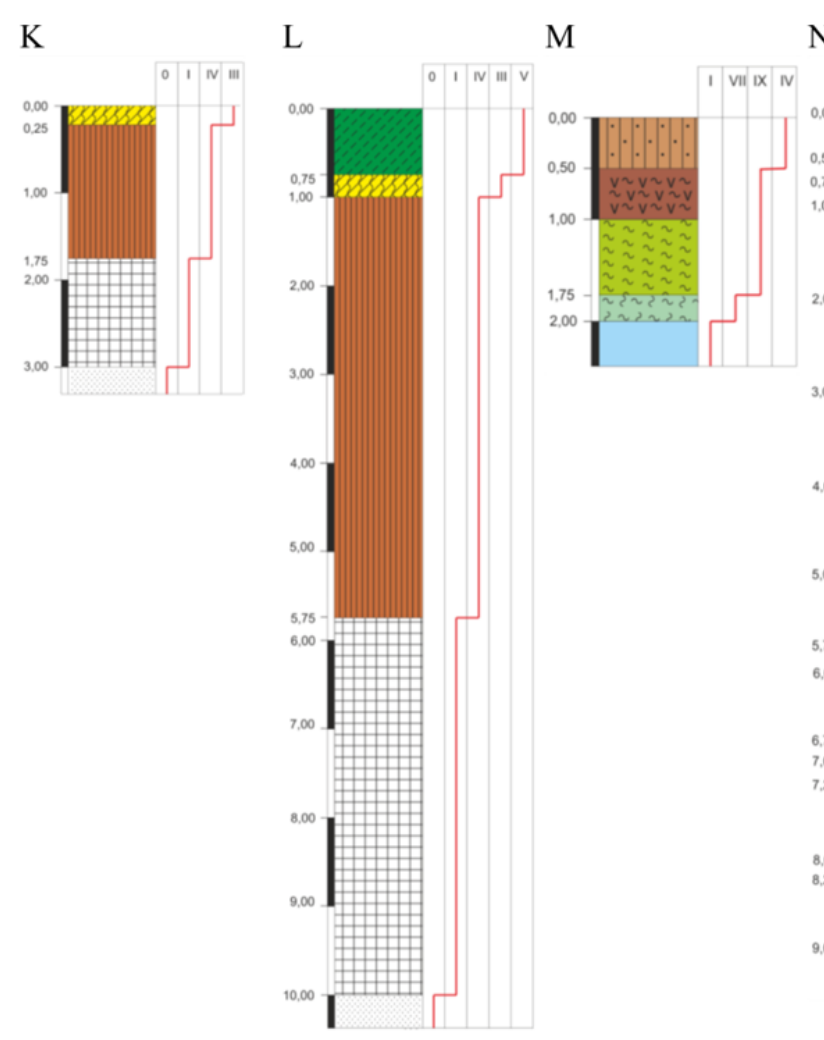

$\mathrm{N} \quad \mathrm{O}$

$P$

Explanations:

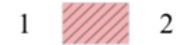

11
2

12

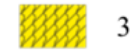

3

13
4

14

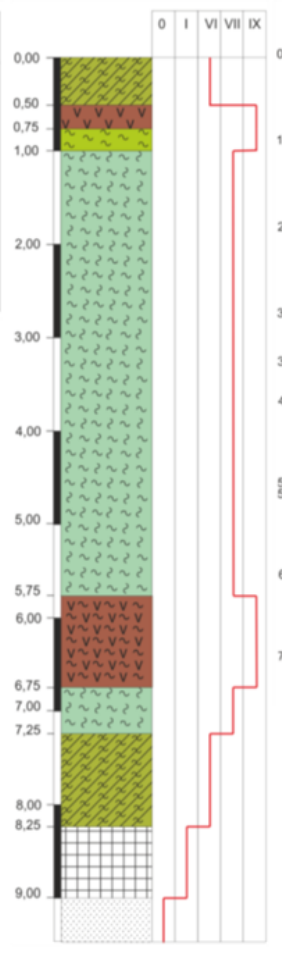

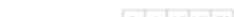

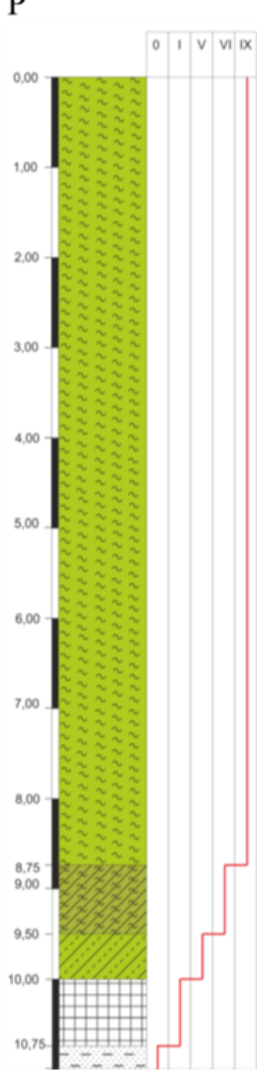

Fig. 2. Dynamic curve of the lithological sequence in peat deposit: A: Puścizna Wielka (No 1) (source: LIPKA, ZAJĄC [2014], changed); B: Bór za Lasem (No 2) (source: LIPKA, ZAJĄC [2014], changed); C: Wołosate (No 3); D: Targowisko (No 4); E: Wielkie Błoto (No 5); F: Błonie (No 6) (source: LIPKA [2000], changed); G: Wojsławka (No 7) (source: LIPKA [2000], changed); H: Całowanie (No 8); I: Wieprz-Krzna near Radzyń Podlaski (No 9) (source: LIPKA [2000], changed);

J: Koniuszki (Basen Górnej Biebrzy) (No 10) (source: LIPKA [2000], changed); K: Kłębowiec (No 11); L: Bielice (No 12); M: Pniów I (No 13); N: Pniów II (No 14); O: Piersele (No 15); P: Warszkajty (No 16); $1=$ Cariceti peat,

$2=$ Cariceto-Phragmiteti peat, $3=$ Phragmitet $i$ peat, $4=$ Cariceto-Bryaleti peat, $5=$ Cariceto-Bryaleti peat with clay admixture, $6=$ Alneti peat, $7=$ Betuleti peat, $8=$ Bryaleti peat, $9=$ Sphagno-Cariceti peat, $10=$ Eusphagneti peat, $11=$ Eriophoro-Sphagneti peat, $12=$ Pinet $i$ peat, $13=$ Pino-Sphagneti peat, $14=$ humified peat, $15=$ gyttja, $16=$ sand, $17=$ clay, $18=$ clay with admixture of sand, $19=$ water; source: own elaboration

tion of habitats and gradual transformation of fens into bogs are very often related to geomorphological processes. In the case of Wołosate, these processes resulted in a transition of the peatland from the valley axis to a floodplain terrace due to deep erosion of the watercourse.

\section{PEATLANDS OF OLD GLACIAL AREA}

Wielkie Błoto (No 5) peatland (Fig. 2E) was formed in a post glacial depression within an older terrace of the Vistula ice marginal valley. Waterlogging and hindered water runoff (HC I) resulted in calcareous gyttja formation on the bottom of the depression. The layer of reed peat was formed in HC II, i.e. almost year-round inundation with predominantly stagnant water supplied mainly with precipitation water. As the intensity and importance of inundation in ombrogenic-inundation water regime of the peatland decreased, reed vegetation gradually declined and sedge communities developed. This was reflected in peat sequence of sedge-reed, and then sedge (Cariceti) peats formed in HC III. The roof layer was an amorphous peat formed after drainage of a large part of the peatland in $19^{\text {th }}$ century [LIPKA 1989], which resulted in a general decrease of groundwater level ( $\mathrm{HC} \mathrm{X})$ and consequently degradation of substantial area of the peatland.

Formation of a fen Wojsławka (No 7) (Fig. 2G) was shaped mainly by the HC V. The peatland was formed in a closed depression layered with poorly permeable clay. Initial plant communities on the clay substrate formed a thin layer of sedge-moss peat covered with a shallow layer of gyttja (HC I). At the next stage, alimentation was based on constant supply of groundwater but inundation water was also periodically more or less important. Gyttja, in the conditions of short-term river flood (HC IV), was covered with 
alder peat. Reduced intensity and duration of floods accompanied by an increase in ground water supply (HC V) favoured formation of sedge-moss peat. Periodic floods were evidenced by the presence of clay in the upper layer of this peat. When the inundation ceased, moss peat (Bryaleti) was formed in the roof layer of the deposit. Drainage of the peatland inhibited peat formation process and initiated its degradation (HC D).

\section{PEATLANDS OF YOUNG GLACIAL AREA}

A very deep Bielice (No 12) peatland (Fig. 2L) originated from a terrestrialization of postglacial flow-through lake in the valley of the Ilanka River. A considerably thick $(4.5 \mathrm{~m})$ layer of organic and calcareous gyttja (HC I) was formed at the bottom of the lake. When the depression shallowed, peatland formed under prevailing HC IV. Periodic inundation resulted in a formation of a nearly $5 \mathrm{~m}$ thick deposit of alder peat. Peat types in the roof layer indicated decreasing frequency and intensity of river flooding and increasing share of groundwater supply in the peatland hydrology. The roof zone included a thin layer of sedge-reed peat formed in $\mathrm{HC}$ III covered with moss peat formed in $\mathrm{HC} \mathrm{V}$ characterized by drainage of groundwater, but with no flooding. A similar pattern of ecohydrological development was observed for a much shallower Kłębowiec (No 11) peatland (Fig. 2K).

Interesting sites of young glacial area are kettle hole mires that have been so far poorly recognized but have been recently attracting increasing attention of researchers (e.g. TOBOLSKI [2003]; LAMENTOWICZ et al. [2007]; KOWALEWSKI, ŻUREK [2011]). Examples include the peatlands around Pniów (No 13 and 14) (Fig. 2M, N) or Warszkajty (No 16) peatland (Fig. 2P). These are peatlands formed mainly in HC IX supplied with precipitation water. The peatlands Pniów II (No 14) (Fig. 2N) and Warszkajty were formed over gyttja sublayer (HC I). In the beginning, their development depended on the supply of groundwater. Accumulation of peat caused gradual isolation of the peatland area from the surrounding regional gorundwater table and a transition to ombrogenic water supply. The profile of Warszkajty peatland revealed organic and calcareous gyttja covered with a thin layer of sedge-moss fen peat (HC V), over which Sphagnum-sedge (Sphagno-Cariceti) transitional peat was formed. The appearance of transitional peat indicated ombrogenic-drainage type of water regime, with a distinctly declining share of the latter (HC VI). No fen peat was detected over clay gyttja in Pniów II peatland. In both peatlands the transitional peat was covered by different types of ombrogenic peats depending on the hydration state of the peatland, sometimes of considerable thickness. Progressive rise of water level in peat with its periodic oscillations (HC VII) facilitated formation of cotton grassSphagnum peat (Pniów II). Lowered groundwater level and so drier conditions, i.e. in HC IX, was conducive to the formation of thin layers of pineSphagnum (Pino-Sphagneti) or pine wood peats (Pniów I and II), indicating the "hummock-forest phase" of the peatland development, or hummock Sphagnum peat (in Warszkajty peatland it is a homogeneous, over $8 \mathrm{~m}$ thick layer). Warszkajty is a bog, while Pniów I and II are of transitional type. Pniów peatlands were formed in the $\mathrm{HC} \mathrm{VI}$ and contain thin layers of transitional peats of birch (Betuleti) (Fig. 2M) or Sphagnum-sedge type (Fig. 2N), which indicated the presence of groundwater or nutritious runoff from surrounding areas. The peatland Pniów I (Fig. $2 \mathrm{M}$ ) is a typical example of overgrowing of a kettle hole by a floating mat. A small, only 0.5 ha Pniów II (Fig. 2N) peatland originated in a similar way, and its original lake was completely terrestrialised.

The course of the presented dynamic curves indicated that the trajectory of vegetation changes and consequently peat sequence in a deposit were determined by changes in a hydrological factor, i.e. mainly quantity and quality of supplying water. This depends primarily on climatic and hydrogeological conditions, hydrographic network, fluctuations of ground water level, cessation or occurrence of long term floods or intensity of surface and groundwater supply (e.g. OŚWIT [1975]). Recent research demonstrated that the changes in hydrogeological conditions during development of peatlands were complex processes and might be due to different, sometimes overlapping causes. Peatland transformation may be caused by autogenic processes, e.g. plant succession resulting in terrestrialization and transition from a lake to a fen and finally a bog (e.g. KULCZYŃSKI [1939-1940; 1949]; Hughes, BARBER [2003]; URBAN, TOKARZ [2014]). However, the expected direction of an autogenic succession might be modified by an external allogenic factor [TUITTILA et al. 2007], such as climatic changes that particularly affect ombrotrophic bogs (e.g. GUNARSSON et al. [2003]; CHARMAN et al. [2006]; EDVARDSSON et al. [2012]), or anthropogenic pressure in the form of deforestation, drainage or fires (e.g. Sillasoo et al. [2011]; STIVRINS et al. [2017]). While interpreting the sequence of sediments in a deposit one should remember that hydrological changes may be of gradual but also of sudden and fierce nature, which may result in a lack of some transition stages in the series of succession (hiatus) (e.g. MAREK [1965]; OśwIT [1975]). In this case, the arrangement of individual peats in the profile usually differs from the most common sequences. The sequence indicating anomalies in natural stages of a peatland development, e.g. the presence of sedge or reed peats over moss peats, fen peats over transitional ones or gyttja over fen peats usually reflected climate changes including increased humidity or rising sea level or local groundwater level, or was due to the anthropogenic pressure [ŻUREK 1993]. However, relative effects of internal (autogenic) and external (allogenic) processes on changes in hydrological conditions in a peatland, 
and therefore in the peatland ecohydrology may be difficult to determine unambiguously, and the effects of a climate on changes in water table depth are in some cases overestimated [MORRIS et al. 2011; SWINDLES et al. 2012].

\section{CONCLUSIONS}

Considering the complexity of peatland paleoecology and paleohydrology, we presented a proposal of the dynamic curve method. The method and a concise description of hydrological conditions (HC) facilitating formation of particular biogenic sediments (bottom deposits, peats) constitute a simplified approach but the method can be used for general interpretation of local hydrological conditions of peatland formation that would allow for skipping some highly specialized research. This approach may prove useful particularly in engineering practice. It could be also helpful for specialists from other fields, e.g. geologists, biologists or representatives of administration or non-governmental organizations, who are not deeply involved in peat research. However, to refine the method and determine its error, it needs to be verified by the use of other methods (multi-proxy studies).

\section{Acknowledgements}

This research was carried out within Projects DS3331/KMIKŚ/2016 financed from a research grant allocated by the Polish Ministry of Science and Higher Education.

\section{REFERENCES}

AleXANDRowicz S.W. 1978. Krzywa dynamiczna profilu litostratygraficznego [Dynamic curve of a lithostratigraphic profile]. Manuscript. Kraków. Instytut Geologii i Surowców Mineralnych AGH.

ANDERSSON S., SCHONING K. 2010. Surface wetness and mire development during the late Holocene in central Sweden. Boreas. Vol. 39 p. 749-760.

BARBER K. 1993. Peatlands as scientific archives of past biodiversity. Biodiversity and Conservation. Vol. 2. Iss. 5 p. 474-489.

Chambers F.M., Charman D.J. 2004. Holocene environmental change: Contributions from the peatland archive. The Holocene. Vol. 14. Iss. 1 p. 1-6.

Charman D.J., Blundell A., Chiverrell R.C., Hendon D., LANGDON P.G. 2006. Compilation of non-annually resolved Holocene proxy climate records: stacked Holocene peatland palaeo-water table reconstructions from northern Britain. Quaternary Science Reviews. Vol. 25 p. 336-350.

Damman A.W., French T.W. 1987. The ecology of peat bogs in the glaciated northeastern United States: A community profile. U.S. Fish and Wildlife Service, Washington, DC, USA. Biological Report 85 (7.16) pp. 100 .

DemBeK W., Oświt J. 1992. Rozpoznawanie warunków hydrologicznego zasilania siedlisk mokradłowych. W: Hydrologiczne siedliska wilgotnościowe [Recognizing of hydrological supply of wetlands. In: Hydrologenic habitats]. Biblioteczka Wiadomości IMUZ. Nr 79 p. $15-38$.
Dembek W., PióRKowski H., Rycharski M. 2000. Mokradła na tle regionalizacji fizyczno-geograficznej Polski [Wetlands in the context of physical and geographical regionalization of Poland]. Biblioteczka Wiadomości IMUZ. Nr 97. ISSN 0519-7864 pp. 135.

EdVARdSSON J., Linderson H., Rundgren M., HammarLUND D. 2012. Holocene peatland development and hydrological variability inferred from bog-pine dendrochronology and peat stratigraphy - a case study from southern Sweden. Journal of Quaternary Science. Vol. 27. Iss. 6 p. $553-563$.

GaŁka M., Tobolski K., Lamentowicz Ł., ERsek V., JasSEY V.E.J., VAN DER KNAAP W.O., LAMENTOWICZ M. 2017. Unveiling exceptional Baltic bog ecohydrology, autogenic succession and climate change during the last 2000 years in CE Europe using replicate cores, multiproxy data and functional traits of testate amoebae. Quaternary Science Reviews. Vol. 156 p. 90-106.

GunNarson B.E., Borgmark A., WastegaÅrd S. 2003. Holocene humidity fluctuations in Sweden inferred from dendrochronology and peat stratigraphy. Boreas. Vol. 32 p. 347-360.

Hughes P.D.M., BARBER K.E. 2003. Mire development across the fen-bog transition on the Teifi floodplain at Tregaron Bog, Ceredigion, Wales, and a comparison with 13 other raised bogs. Journal of Ecology. Vol. 91. Iss. 2 p. $253-264$.

ILNICKI P. 1996. Wetlands in the Poznan region of Poland. Proccedings of $10^{\text {th }}$ International Peat Congress. Ed. G.W. Luttig. Bremen, 27.05-02.06.1996. Vol. 2 p. 488496.

ILNICKI P. 2002. Torfowiska i torf [Peatlands and peat]. Poznań. Wydaw. AR. ISBN 83-7160-243-X pp. 606.

KAC N.J., KaC S.W., SKOBEEVA E. 1977. Atlas rastitel'nych ostatkov $\mathrm{v}$ torfach [Atlas of plant remains in peats]. Moskva. Nedra pp. 371.

KONDRACKI J. 2011. Geografia regionalna Polski [Regional geography of Poland]. Warszawa. Wydaw. Nauk. PWN. ISBN 9788301160227 pp. 468.

KowALEWSKI G., ŻUREK S. 2011. Geology and developmental pathways of sphagnum peatland-lake ecosystems in Eastern Pomerania. Studia Quaternaria. Vol. 28 p. 41-52.

KULCZYŃSKi S. 1939-1940. Torfowiska Polesia [Peatlands of Polesie]. T. 1, 2. Kraków. Księg. Gebethnera i Wolfa pp. 777.

KulCZYŃSKi S. 1949. Peat bogs of Polesie. Mémoires de l'Académie Polonaise des Sciences et des Lettres, Classe des Sciences Mathématiques et Naturelles. Séries B: Sciences Naturelles 15 pp. 359.

Lamentowicz M., Milecka K., Galka M., Cedro A., Pawlyta J., Piotrowska N., LAMENTOWicz Ł., VAN DER KNAAP W.O. 2009. Climate and human induced hydrological change since AD 800 in an ombrotrophic mire in Pomerania ( $\mathrm{N}$ Poland) tracked by testate amoebae, macro-fossils, pollen and tree rings of pine. Boreas. Vol. 38. Iss. 2 p. 214-229.

Lamentowicz M., Tobolski K., Mitchell E.A.D. 2007. Palaeoecological evidence for anthropogenic acidification of a kettlehole peatland in northern Poland. The Holocene. Vol. 17. Iss. 8 p. 1185-1196.

LINDSAY R. 2016. Peatland classification. In: The wetland book. Eds. C.M. Finlayson, M. Everard, K. Irvine, R. McInnes, B. Middleton, A. van Dam, N.C. Davidson. Springer p. 1-14.

LIPKA K. 1973. Torfowiska Puszczy Niepołomickiej [Peatbogs of forest Puszcza Niepołomicka]. Zeszyty Nauko- 
we AR w Krakowie. Ser. Melioracje. Nr 79. Z. 6 p. $101-120$.

LIPKA K. 1984. Charakterystyka torfowisk i złóż torfowych w Makroregionie Środkowowschodnim. W: Surowce mineralne środkowo-wschodniej Polski [Characteristics of peatlands and peat deposits in Middle Eastern Macroregion. In: Mineral raw materials of Central and Eastern Poland]. Ed. S. Kozłowski. Warszawa. Wydaw. Geologiczne p. 69-83.

LIPKA K. 1989. Torfowisko „Wielkie Błoto” w Puszczy Niepołomickiej. W: Przewodnik 60. Zjazdu Polskiego Towarzystwa Geologicznego [„Wielkie Błoto” peatland in the Niepołomice Forest. In: Guide to the 60th Congress of the Polish Geological Society]. Kraków. Wydaw. AGH p. 143-146.

LIPKA K. 1995. Stratygrafia torfowisk w Bieszczadach Zachodnich. W: Torfoznawstwo w badaniach naukowych i praktyce [Stratigraphy of peatlands in the Western Bieszczady Mountains. In: Peat science in research and practice]. Falenty. Wydaw. IMUZ. Materiały Seminaryjne. Nr 34 p. 89-102.

LIPKA K. 2000. Torfowiska w dorzeczu Wisły jako element środowiska przyrodniczego [Peat bogs in the Wisła River basin as an element of the natural environment]. Zeszyty Naukowe AR w Krakowie. Ser. Rozprawy. Z. 255 pp. 148.

LIPKA K., FrANKIEWICZ J.K. 1981. Torfowiska w dolnie rzeki Ilanki (woj. zielonogórskie) [Peatbogs in the Valley of the River Ilanka (Province of Zielona Góra)]. Zeszyty Naukowe AGH w Krakowie. Ser. Geologia. T. 6. Z. 4 p. 83-98.

LIPKA K., GoDZIEMBA-CZYŻ W. 1970. Torfowiska i młaki zlewni potoku Wołosatka w Bieszczadach Zachodnich [The peat-bogs and swamps in the watershed of stream Wołosatka (Western Bieszczady Mts)]. Zeszyty Naukowe WSR w Krakowie. Ser. Melioracje. Z. 4 p. 3-26.

LiPKa K., MaŚlanKa K., UrbanOwicz A. 1977. Przyczyny złego stanu zmeliorowanej łąki torfowej na przykładzie obiektu Błonie w woj. kieleckim [Causes of bad condition of drained peat grassland on the example of Błonie in Kielce Provence]. Wiadomości Melioracyjne i Łąkarskie. Nr 8-9 p. 219-221.

LIPKA K., ZAJĄC E. 2014. Stratygrafia torfowisk Kotliny Orawsko-Nowotarskiej [Stratigraphy of peatlands in the Orawa-Nowy Targ Basin]. Kraków. Wydaw. Art-Tekst. ISBN 9788377831045 pp. 133.

LIPKA K., ZAJĄC E., ZARZYCKI J. 2006. Course of plant succession in the post-harvested and post-fire areas of the Wielkie Błoto fen in the Niepołomicka Primeval Forest. Acta Agrophysica. Vol. 7. Nr 2 p. 433-438.

EAJCZAK A. 2013. Role of land relief and structure in the formation of peat bogs in mountain areas, as exemplified by the Polish Carpathians. Landform Analysis. Vol. 22 p. $61-73$.

MAREK S. 1965. Biologia i stratygrafia torfowisk olszynowych w Polsce [Biology and stratigraphy of alder mires in Poland]. Zeszyty Problemowe Postępów Nauk Rolniczych. Z. 57 p. 5-304.

Mauquoy D., van Geel, B. 2007. Mire and peat macros. In: Encyclopedia of Quaternary Science. Ed. S.A. Elias. Amsterdam. Elsevier B.V. p. 2315-2336.

Mauquoy D., Yeloff D., Van Geel B., Charman D.J., BLUNDELL A. 2008. Two decadally resolved records from north-west European peat bogs show rapid climate changes associated with solar variability during the midlate Holocene. Journal of Quaternary Science. Vol. 23. Iss. 8 p. $745-763$.
MizerSKi W., SylwestrZaK H. 2002. Słownik geologiczny [Geological dictionary]. Warszawa. Wydaw. Nauk. PWN. ISBN 8301137819 pp. 244.

MorRis P.J., BelYeA L.R., BAIRD A.J. 2011. Ecohydrological feedbacks in peatland development: a theoretical modelling study. Journal of Ecology. Vol. 99. Iss. 5 p. 1190-1201.

MR 1959. Tymczasowa instrukcja w sprawie wstępnych badań torfowisk [Temporary instructions for preliminary study of peatlands]. Warszawa. Ministerstwo Rolnictwa, Departament Wodnych Melioracji. Manuscript.

OKRUSZKo H. 1983. Zróżnicowanie warunków hydrologicznych mokradeł $\mathrm{w}$ aspekcie ich melioracji [Diversification of hydrological conditions of wetlands in the aspect of their drainage]. Wiadomości IMUZ. T. 15. Z. 1 p. $13-31$.

OKRUSZKO H. 1992. Siedliska hydrogeniczne, ich specyfika i zróżnicowanie [Hydrogenic habitats, their specificity and diversity]. Biblioteczka Wiadomości IMUZ. Nr 79 p. 5-14.

Okruszko H., Dembek W., Oświecimska-Piasko Z. 2001. Geomorfologia a mokradła jako problem naukowy [Geomorphology and wetlands as scientific problem]. WodaŚrodowisko-Obszary Wiejskie. T. 1. Z. 3 p. 17-21.

OKRUSzKo H., Oświt J. 1991. Hydrologiczny podział torfowisk w ujęciu Kulczyńskiego [Hydrological division on of peatlands in terms of Kulczyński]. Biuletyn Torf. Nr 1/2/107/108 p. $3-8$.

OśwIT J. 1975. Układy glebowo-stratygraficzne torfowisk jako wynik sukcesji i warunków hydrologicznych [Stratigraphic arrangement of of peat soil profiles in consequence of plant succesion and hydrological condistions]. Roczniki Nauk Rolniczych. Ser. F. T. 79. Z. 1 p. $151-162$.

OśwIT J. 1977. Naturalne siedliska torfowe jako podstawa wyróżniania jednostek przyrodniczych [Natural peat habitats as the basis for distinguishing natural units]. Roczniki Nauk Rolniczych. Ser. F. T. 1. Z. 3 p. 29-50.

Oświt J., DembeK W. 2001. Geomorfologiczno-hydrologiczne uwarunkowania rozwoju mokradeł na przykładzie torfowiska Całowanie w dolinie środkowej Wisły [Geomorphological-hydrologiacal conditions of wetlands development on the example of the Całowanie peatland in the Middle Wisła Valley]. Woda-Środowisko-Obszary Wiejskie. T. 1. Z. 3 p. 119-134.

PN-G-0459 1997. Torfy i wyroby z torfu. Oznaczanie stopnia rozkładu [Peat and peat production. Determination of degree of decomposition]. Polski Komitet Normalizacyjny pp. 9.

Sillasoo Ü., VÄliranta M., Tuittila E.-S. 2011. Fire history and vegetation recovery in two raised bogs at the Baltic Sea. Journal of Vegetation Science. Vol. 22. Iss. 6 p. 1084-1093.

Stivrins N., Ozola I., GaŁKa M., Kuske E., Alliksaar T., Andersen T.J., Lamentowicz M., Wulf S., Reitalu T. 2017. Drivers of peat accumulation rate in a raised bog: impact of drainage, climate, and local vegetation composition. Mires and Peat. Vol. 19 p. 1-19.

Swindles G.T., Morris P.J., Baird A.J., BlaAuw M., PlunKETT G. 2012. Ecohydrological feedbacks confound peat-based climate reconstructions. Geophysical Research Letters. Vol. 39. Iss. 12 L11401.

ToBolsKi K. 2000. Przewodnik do oznaczania torfów i osadów jeziornych [A guide for the determination of peat and lake sediments]. Warszawa. Wydaw. Nauk. PWN. ISBN 83-01-13215-9 pp. 508. 
TOBOLSKI K. 2003. Torfowiska na przykładzie Ziemi Świeckiej [Peatlands of on the example Świecie Region]. Świecie. Towarzystwo Przyjaciół Dolnej Wisły. ISBN 83-919299-1-4 pp. 255.

TOBOLSKI K. 2004. Kryterium geologiczne w badaniach zbiorników akumulacji biogenicznej [Geological criteria in the studies of biogenic accumulation basins]. Kieleckie Towarzystwo Naukowe, Regionalny Monitoring Środowiska Przyrodniczego. Nr 5 p. 119-126.

TOŁPA S., JASNOWSKI M., PAŁCZYŃSKI A. 1971. New classification of peats based on phytosociological methods. Bulletin International Peat Society. Vol. 2 p. 9-14.

TOŁPA S., JASNOWSKI M., PAŁCZYŃSKi A. 1967. System der genetischen Klassifizierung der Torfe Mitteleuropas [The peat genetic classification system in Central Europe]. Zeszyty Problemowe Postępów Nauk Rolniczych. Nr 76 p. 9-99.

Tuittila E.-S., VÄliranta M., Laine J., Korhola A. 2007. Quantifying patterns and controls of mire vegetation succession in a southern boreal bog in Finland using partial ordinations. Journal of Vegetation Science. Vol. 18. Iss. 6 p. 891-902.

Urban D., TOKARZ E. 2014. Development of plant communities in the uroczysko jęzor peatbog indicated by analysis of macrofossil plant remains. Teka Komisji Ochrony Kształtowania Środowiska Przyrodniczego O.L. PAN. Nr 11 p. 236-248.

VÄliranta M., Blundell A., Charman D.J., Karofeld E., Korhola A., Sillasoo Ü.-S., TuitTIla E.-S. 2012. Reconstructing peatland water tables using transfer functions for plant macrofossils and testate amoebae: a methodological comparison. Quaternary International. Vol. 268. Iss. 3 p. 34-43.

VAN DER KNAAP W.O., LAMENTOWICZ M., VAN LEEUWEN J.F.N., Hangartner S., Leuenberger M., Mauquoy D., Goslar T., Mitchell E.A.D., Lamentowicz Ł., KAMENIK C. 2011. A multi-proxy, high-resolution record of peatland development and its drivers during the last millennium from the subalpine Swiss Alps. Quarternary Science Reviews. Vol. 30. Iss. 23-24 p. 34673480.

VITT D.H. 2006. Functional characteristics and indicators of boreal peatlands. In: Boreal peatland ecosystems. Eds. R.K. Wieder, D.H. Vitt. Ecological Studies. Vol. 188 p. 9-22.

Wheeler B.D., Proctor M.C.F. 2000. Ecological gradients, subdivisions and terminology of north-west European mires. Journal of Ecology. Vol. 88 p. 187203.

Woś A. 2010. Klimat Polski w drugiej połowie XX wieku [Climate of Poland in the second half of the 20th century]. Poznań. Wydaw. Nauk. UAM. ISBN 978-83232-218-7 pp. 489.

ŻUREK S. 1987. Złoża torfowe Polski na tle stref torfowych Europy [The peat deposits of Poland against the peat zones of Europe]. Dokumentacja Geograficzna IGiPZ PAN. Z. 4 pp. 84.

ŻUREK S. 1993. Zmiany paleohydrologiczne w mokradłach [Palaeohydrological changes in the wetlands]. Przegląd Geograficzny. T. 64. Z. 1-2 p. 75-95.

\section{Krzysztof LIPKA, Ewelina ZAJĄC}

\section{Warunki hydrologiczne powstawania torfowisk na podstawie krzywej dynamicznej sekwencji osadów biogenicznych - nowa propozycja}

\section{STRESZCZENIE}

Celem pracy było przedstawienie propozycji wykorzystania tzw. krzywej dynamicznej do określenia warunków hydrologicznych powstawania torfowisk. Posługując się proponowaną metodą, można w prosty sposób zinterpretować przebieg procesu akumulacji na podstawie sekwencji osadów biogenicznych w zależności od zmieniających się warunków hydrologicznych. Mając na uwadze ekohydrologiczne zależności skutkujące powstawaniem torfowisk, wyróżniono i opisano jedenaście typów warunków hydrologicznych (HC), którym przyporząadkowano określone gatunki torfu ujęte w klasyfikacji opracowanej dla obszaru środkowej Europy. Posługując się syntetycznym opisem wydzielonych HC, można, za pomocą krzywej dynamicznej, graficznie zilustrować stan uwodnienia profilu geologicznego oraz zinterpretować przebieg zmian stosunków wodnych $\mathrm{w}$ trakcie formowania się torfowiska. Zaproponowana metoda stanowi pewne uproszczenie, niemniej może być stosowana do ogólnej interpretacji warunków hydrologicznych powstawania złóż torfowych z pominięciem niektórych, wysoce specjalistycznych badań. Takie podejście może okazać się wystarczające zwłaszcza w praktyce inżynierskiej.

Słowa kluczowe: geologia torfowisk, hydrologia torfowisk, krzywa dynamiczna, sekwencja osadów biogenicznych, szczątki roślinne 